\title{
G.
}

ISSN 2278 - 0211 (Online)

\section{Economic Analysis of Cattle Fattening among Beneficiaries and Non- Beneficiaries of Bank of Agriculture Micro Credit in Some Selected Local Government Areas of Sokoto State, Nigeria}

\begin{tabular}{|c|}
\hline 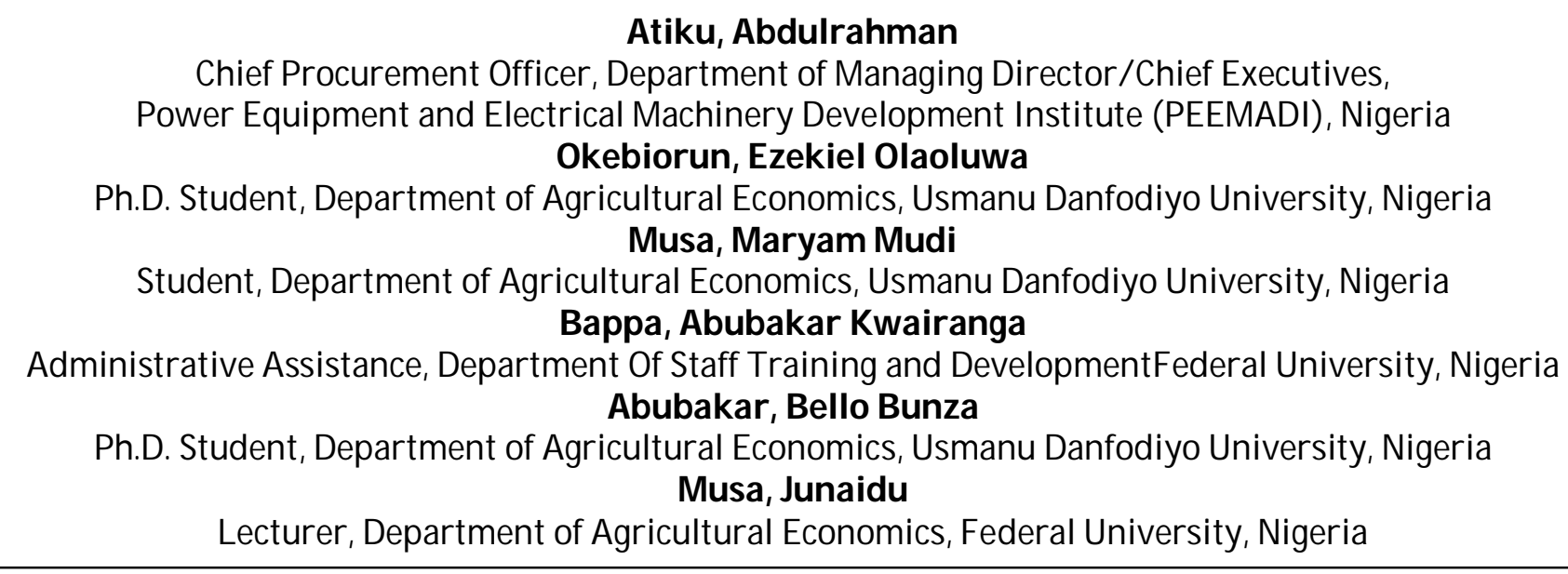 \\
\hline
\end{tabular}

\begin{abstract}
:
The study assessed the economic analysis of cattle fattening among beneficiaries and non-beneficiaries of Bank of Agriculture micro credit in some selected Local Government Areas of Sokoto State. Data were collected with the aid of structured questionnaire administered to 300 cattle fatteners. Simple random technique was used to select 150 micro credit beneficiaries and 150 non-beneficiaries. Data collected were analyzed using descriptive statistics and farm budgeting model. The results revealed that $94.7 \%$ of beneficiaries and $98 \%$ of non-beneficiaries were male with the mean age of 46 and 44 years for beneficiaries and non-beneficiaries respectively. Almost all of the respondents ( $92 \%$ of beneficiaries and $97.3 \%$ nonbeneficiaries) are married with $68.6 \%$ of beneficiaries and 70\% non-beneficiaries having family size ranging from 6 to 10 . More so, $41.3 \%$ and $48.3 \%$ of beneficiaries and non-beneficiaries respectively admitted that farming and Cattle fattening is their major occupation. In term of years of fattening experience, only 18\% of beneficiaries and $28.7 \%$ non-beneficiaries had more than 10 years of experience. Similarly, results of the farm budget analysis revealed that, an average net income of $\$ 37,863.42$ and $\$ 20,680.51$ per cattle fattened were realized by beneficiaries and non-beneficiaries respectively. It is therefore concluded that micro-credit of Bank of Agriculture has positive impact on beneficiaries as they realized more income than non-beneficiaries in the study areas. It is recommended that the bank should decentralize approval powers to branches in order to make loan easier for the cattle fatteners.
\end{abstract}

Keywords: Analysis, cattle, economic, farmer, fattening, micro credit, Sokoto State

\section{Introduction}

The role of microcredit in agricultural development is enormous. Credit is the backbone for any business and more so for agriculture which has traditionally been a non-monetary activity for the rural population in Sokoto State, Nigeria. Micro credit has evolved over the years and does not only provide credit to the poor but now spans a myriad of other services such as savings, insurance, remittances and non-financial services such as financial literacy training and skill development programme and is hence now referred to as microfinance (Armendáriz de Aghion et al, 2010). However, microcredit is a way of delivering loans to poor individuals and is often suggested to be a way out of poverty (Armendáriz de Aghion et al, 2010). Micro financing is the provision of financial services to poor and low income households without access to formal financial institutions (Conroy, 2003). Access to financial services enables poor household to move from everyday for survival to planning for the future, investing in better nutrition, their children`s education and health and empowering women socially (Ehigiamusoe, 2005). 
Cattle fattening sub-sector is vital within the agricultural sector in Nigeria with specific economic importance due to its high contribution in the value of the livestock sector. Cattle fattening is one of the most important economic activity to the small holder farmers in Sokoto State, Nigeria with an estimated livestock population of 1.18 million cattle, nearly 2.90 million goats, 1.98 million sheep, 2 million chickens, 45,000 camels, 34,532 horses, and 51,388 donkeys (Sokoto State`s Guide to Economic Potential, 2008). The importance of micro credit on cattle fattening enterprise cannot be overemphasized because it improves cattle fattening in the significant adjustment in the production trend of cattle products through the injection of capital to the fatteners thereby stimulating increase in beef / animal protein production. The impact recorded by beneficiary cattle fatteners includes increased production of beef hence more income and wealth generation thereby improving the standard of living of the fatteners in the study area. The credit also provides employment and job creation for the fatteners. Proponents state that it reduces poverty through higher employment and incomes. This is expected to lead to improved nutrition and improved education of the borrowers' children. Some argue that microcredit empowers women Goldberg (2005). Tazul, (2007) asserts a positive influence of microcredit on the level of education, health and nutrition.

Cattle fattening in particular has received less attention than crop and vegetable cultivation. It is in view of the importance of micro-credit on agricultural enterprises and cattle's fattening in particular, this paper tries to contribute to our understanding of bank of agriculture micro credit among cattle fatteners by considering the case of beneficiaries and nonbeneficiaries of bank of agriculture micro credit in the study area. Thus, the main objective of this study is to determine the economic analysis of cattle fattening among beneficiaries and non-beneficiaries of bank of agriculture micro credit in some selected Local Government Areas of Sokoto State, Nigeria. The specific objectives are to: describe the socio-economic characteristics of cattle fatteners and determine the cost and returns associated with cattle fattening among beneficiaries and non-beneficiaries of bank of agriculture micro credit in the study area.

\section{Methodology}

\subsection{Study Area}

The study was conducted in some selected Local Government Areas (LGAs) of Sokoto State, North western Nigeria. The State falls within latitudes $4^{0}-6^{0} 40^{\prime} \mathrm{N}$ and longitudes 11030' - 13050'E. It is bounded to the West and North by Niger Republic, to the East by Zamfara State and to the south by Kebbi state. The total land mass is 26, 648.48 square kilometers (SOSG, 2007). It is located in the Sudan savannah ecological zone. The area is situated in the semi-arid climate zone of Nigeria with a long, dry and hot season. "Rainfall starts late and ends early with an annual fall ranging between $500 \mathrm{~mm}$ to $1300 \mathrm{~mm}$. The State is characterized by low vegetation and few trees of medium height scattered about. This provides a good habitat for variety of livestock production activities, which includes rearing of cattle. Agriculture sector occupies a very important position in the economic life of the people of Sokoto State.

The major crops grown in the State include cereals like sorghum, millet, and rice; legumes like cowpea/ beans and groundnut. Other crops like onion, garlic and pepper are grown in the dry season. The people in the area are also engaged in livestock production such as cattle, sheep/ goat, fish, poultry, camels and donkeys. The total projected population of Sokoto State is 4,683,248 (NPC, 2006). The major ethnic groups in the State are Hausas and Fulanis. Apart from Hausa and Fulani, there are the Zabarmawa minorities. All these groups speak Hausa as a common language. Fulfulde is spoken by the Fulani. The people in the area are predominantly small scale farmers who produce on subsistence level through the use of crude and/ or traditional methods/implement such as hoes, cutlasses, knives and axes. They are also engaged in other income generating activities like trading, transport business and public service.

\subsection{Sampling Procedure and Sample Size}

The population of the study includes micro credit beneficiaries and non-beneficiaries in some selected Local Government Areas of Sokoto State. The study adopted multi-stage random and purposive sampling technique. In the first stage, three (3) Local Government Areas were purposively selected (Tangaza, Gudu and Kware Local Government Areas) because of their predominance in cattle production. The second stage involved the random selection of three (3) villages from each of the selected Local Government Areas.

The third stage involves proportionate selection of cattle fatteners from each villages, this was based on the total list of cattle fattening loan beneficiaries obtained from credit department of the bank and non-beneficiary farmers obtained from the extension agent in the study area. One hundred and fifty (150) cattle fatteners each were selected using simple random techniques from micro credit beneficiaries and non-beneficiaries respectively, to give a total number of Three hundred (300) cattle fatteners (Table 1). 


\begin{tabular}{|c|c|c|c|c|c|}
\hline Lga & Villages & $\begin{array}{c}\text { Number of } \\
\text { Beneficiaries }\end{array}$ & $\begin{array}{c}\text { Number of } \\
\text { Sample Farmers }\end{array}$ & $\begin{array}{c}\text { Number of } \\
\text { Non Beneficiaries }\end{array}$ & $\begin{array}{c}\text { Number of } \\
\text { Sample Farmers }\end{array}$ \\
\hline Tangaza & Tangaza & 200 & 30 & 200 & 30 \\
& Gidan Madi & 160 & 24 & 160 & 24 \\
& Gongono & 50 & 7 & 50 & 7 \\
Gudu & Balle & 80 & 12 & 85 & 13 \\
& Bachaka & 150 & 22 & 150 & 17 \\
& Karfen Sarki & 120 & 18 & 139 & 21 \\
Kware & Kware & 140 & 21 & 40 & 6 \\
& Hamma Ali & 40 & 6 & 70 & 10 \\
\hline
\end{tabular}

Table 1: Sampling Procedure and Sample Size

Source: Field survey 2014

\subsection{Method of Data Collection and Data Analysis}

Data for the study were collected from both primary and secondary sources. Primary data was collected using a structured questionnaire for the study while the secondary sources data used include the schedule of loan beneficiaries from the bank to compliment the primary source. The analytical tools used to analyze the data generated from the study includes descriptive statistic and budgetary technique which gives the account of net return

\subsubsection{Budgetary Analysis}

The budgetary analysis approach was used to determine cost and returns associated with cattle fattening among beneficiaries and non-beneficiaries of bank of agriculture micro credit in the study area. This was used in estimating the cost and returns associated with cattle fattening enterprise between beneficiaries and non-beneficiaries and determining value added to cattle fattening in terms of profit. According to Olukosi and Erhabo (1989), the aim of farm budgeting is to compare how profitable different kinds of farm enterprise combinations can be. The profitability of beef cattle fattening enterprises was determined by employing farm budget analysis (Okoruwa et al., 2005 and Dawang, 2011).

\begin{tabular}{|c|c|c|}
\hline NFI & $=$ & GFI - TC \\
\hline & $=$ & GFI - (TVC- TFC) \\
\hline TC & $=$ & TVC + TFC \\
\hline Where, & & \\
\hline NFI & $=$ & Net Fattening Income ( \\
\hline GFI & $=$ & Gross Fattening Income \\
\hline TFC & $=$ & Total Fixed Cost of fattening ( \\
\hline TVC & $=$ & Total Variable Cost (\#) \\
\hline
\end{tabular}

\section{Results and Discussion}

\subsection{Socio-Economic Characteristics of the Cattle Fatteners}

Some socio-economic characteristics of the cattle fatteners considered to have influence on their activities include age, sex, marital status, family size, occupation, educational attainment and cattle fattening experience.

\subsubsection{Age of the Cattle Fatteners}

Cattle fattening was practiced by people of different ages in the study area in which the distribution is shown in Table 2. The results show the dominance of people between age group of 31 - 50 years comprising $49.4 \%$ for beneficiaries and $60 \%$ for non-beneficiaries. The mean age of cattle fatteners obtained from the original data in the study area was 46 and 44 years for beneficiaries and non-beneficiaries respectively. This indicates that, majority of the cattle fatteners are within their economically active and productive ages, hence can afford new ideas, manage risks associated with new ideas and/ or practice than older people who are less economically active. The age determines the effort and quality of labour he employs in any given area (Alkali, 2003 cited in Okebiorun and Jatto, 2017). Age is a crucial factor and determinant of attitude. According to Oloruntoba (2000) age is very important in job performance. 


\begin{tabular}{|c|c|c|c|c|}
\hline Age Range (Years) & \multicolumn{2}{|c|}{ Beneficiaries } & \multicolumn{2}{c|}{ Non Beneficiaries } \\
\hline & Frequency & Percent & Frequency & Percent \\
\hline $21-30$ & 11 & 7.3 & 20 & 13. \\
$31-40$ & 33 & 22.0 & 17 & 11.4 \\
$41-50$ & 41 & 27.4 & 73 & 48.6 \\
$51-60$ & 58 & 38.6 & 33 & 21.9 \\
61 and Above & 7 & 4.7 & 7 & 4.8 \\
Mean & 46 & & 44 & \\
\hline Total & 150 & 100 & 150 & 100 \\
\hline
\end{tabular}

Table 2: Age Distribution of the Cattle Fatteners

Source: Field survey 2014

\subsubsection{Gender of the Cattle Fatteners}

Cattle fattening in the study area was predominantly found to be male dominated. Table 3 shows that $94.7 \%$ and $98 \%$ of the beneficiaries and non-beneficiaries respectively are male. Only $5.3 \%$ and $2 \%$ of the beneficiaries and non-beneficiaries are female. Rather than engaging in fattening activities, most female cattle fatteners said it was more lucrative and profitable engaging in dairy production which brings quick money. This result confirms observations by Okoh et al. (2009) that more males were given loans by micro finance institutions.

\begin{tabular}{|c|c|c|c|c|}
\hline Gender & \multicolumn{2}{|c|}{ Beneficiaries } & \multicolumn{2}{c|}{ Non- Beneficiaries } \\
\hline & Frequency & Percent & Frequency & Percent \\
\hline Male & 142 & 94.7 & 147 & 98.0 \\
Female & 8 & 5.3 & 3 & 2.0 \\
\hline Total & 150 & 100 & 150 & 100 \\
\hline
\end{tabular}

Table 3: Distribution of Cattle Fatteners According to Gender

Source: Field survey 2014

\subsubsection{Marital Status of the Cattle Fatteners}

Marital status of cattle fattening farmers influences their population growth and labour supply for fattening operations. Table 4 shows the marital status of the cattle fatteners. The results show that majority $92 \%$ of the beneficiaries and $97.3 \%$ of the non-beneficiaries are married. Married people were therefore, found to be more involved in cattle fattening activity in the study area because as heads of households, they were supposed to earn more income for the running of the day to day activities of their families. The culture of early marriage among the people may be responsible for this and which also ensures good supply of labour on the farm (Maiyamma, 1985). Oladeebo and Oladeebo, (2008) asserted that marriage is an important factor in the livelihood of individuals in our society as it is perceived to confer responsibility on individuals.

\begin{tabular}{|c|c|c|c|c|}
\hline Sex & \multicolumn{2}{|c|}{ Beneficiaries } & \multicolumn{2}{c|}{ Non- Beneficiaries } \\
\hline & Frequency & Percent & Frequency & Percent \\
\hline Married & 138 & 92.0 & 146 & 97.3 \\
Single & 1 & 0.7 & 1 & 0.7 \\
Divorced & 1 & 0.7 & 1 & 0.7 \\
Widow & 10 & 6.7 & 2 & 1.3 \\
\hline Total & 150 & 100 & 150 & 100 \\
\hline
\end{tabular}

Table 4: Marital Status of Cattle Fatteners

Source: Field Survey 2014

\subsubsection{Family Size of the Cattle Fatteners}

The results in Table 5 show that $68.6 \%$ beneficiaries and 70\% of non-beneficiaries have family sizes ranging from 6 to 10. Moreover, $14.7 \%$ and $17.3 \%$ of the beneficiaries and non-beneficiaries respectively, have small family size ranging from 1 to 5 while $16.7 \%$ and $12.7 \%$ of the beneficiaries and non-beneficiaries respectively, have large family sizes of 11 people and above. Family size determines the consumption needs of the household and family labour. The mean family size found in the area was 8 and 7 for beneficiaries and non-beneficiaries respectively. This was largely attributed to the extended family system in the study area. The study are in line with that of Adamu et al., (2013) who reported that average household size in Africa is about 7 persons per household as associated with the tradition, culture and believe in the area. 


\begin{tabular}{|c|c|c|c|c|}
\hline Sex Family Size & \multicolumn{2}{|c|}{ Beneficiaries } & \multicolumn{2}{c|}{ Non- Beneficiaries } \\
\hline & Frequency & Percent & Frequency & Percent \\
\hline $1-5$ & 22 & 14.7 & 26 & 17.3 \\
$6-10$ & 103 & 68.6 & 105 & 70.0 \\
11- and above & 25 & 16.7 & 19 & 12.7 \\
Mean & 8 & & 7 & \\
\hline Total & 150 & 100 & 150 & 100 \\
\hline
\end{tabular}

Table 5: Distribution of Cattle Fatteners by Family Size

Source: Field Survey 2014

\subsubsection{Educational Attainment of the Cattle Fatteners}

Educational attainment is another important socio-economic factor that affects their demand for credit and hence their productivity. As indicated in Table 6, the results revealed that majority (92\% and 80.6) of the beneficiary and nonbeneficiary cattle fatteners respectively were discovered to have formal education while ( $8 \%$ and $19.4 \%$ ) of beneficiary and non-beneficiary cattle fatteners respectively have no formal education. The more educated a farmer is the more he accepts innovations and thus improves his output. Educated farmers are expected to be more receptive to improved farming techniques (Okoye, 2007). Hence, with a higher percentage/ high literacy rate of beneficiaries having western education it is expected that learning and acquisition of improved techniques including access to credit will be increased. This is because the bureaucratic procedures/ paper work is mostly done in western education. The result is in agreement with the work of Musaba (2010) from northern Namibia, who reported that high school education was positively related to the adoption of new cattle management technologies.

\begin{tabular}{|c|c|c|c|c|}
\hline Education & \multicolumn{2}{|c|}{ Beneficiaries } & \multicolumn{2}{c|}{ Non- Beneficiaries } \\
\hline & Frequency & Percent & Frequency & Percent \\
\hline Primary & 73 & 48.7 & 83 & 55.3 \\
Secondary & 43 & 28.6 & 30 & 20.0 \\
Tertiary & 22 & 14.7 & 8 & 5.3 \\
No formal education & 12 & 8 & 29 & 19.4 \\
\hline Total & 150 & 100 & 150 & 100 \\
\hline
\end{tabular}

Table 6: Educational Attainment of the Cattle Fatteners

Source: Field Survey 2014

\subsubsection{Major Occupation of the Cattle Fatteners}

The distribution of cattle fatteners on the basis of major occupation is shown in Table 7. It reveals that majority (53.4\% and $36.4 \%)$ of the beneficiaries and non-beneficiaries respectively, are civil servants. This implies that more civil servants applied for micro credit than non-civil servants in the study area because of their enlightenment and education. Hence, with education it is expected that learning and acquisition of life skills including access to credit will be increased. However, $41.3 \%$ and $48.3 \%$ of beneficiaries and non-beneficiaries respectively are cattle fatteners/ farmers. $5.3 \%$ and $15.3 \%$ of beneficiaries and non-beneficiaries respectively, engaged in petty business and artisans. The result is in agreement with the work of Muhammad (2008) in Kano, Nigeria, found that keeping livestock was a considerable source of additional income for civil servants and traders.

\begin{tabular}{|c|c|c|c|c|}
\hline Occupation & \multicolumn{2}{|c|}{ Beneficiaries } & \multicolumn{2}{c|}{ Non- Beneficiaries } \\
\hline & Frequency & Percent & Frequency & Percent \\
\hline Farming/ Cattle Fattening & 62 & 41.3 & 72 & 48.3 \\
Civil servants & 80 & 53.4 & 55 & 36.4 \\
Petty business/ Artisan & 8 & 5.3 & 23 & 15.3 \\
\hline Total & 150 & 100 & 150 & 100 \\
\hline
\end{tabular}

Table 7: Distribution of Cattle Fatteners by Occupation

Source: Field survey 2014

\subsubsection{Fattening Experience of the Cattle Fatteners}

The productivity of the beneficiaries is expected to be improved considering their years of experience. Table 8 shows the distribution of cattle fatteners according to their experience in fattening. The Table shows that $82 \%$ of the beneficiaries and $71.3 \%$ of non-beneficiaries have between 1 to 10 years of experience in fattening, while none and 1.3\% of beneficiaries and non-beneficiaries respectively have over 20 years fattening experience. Similarly, the more experienced one has in fattening, the more he/ she improves in management of the enterprise hence higher profit margin. 


\begin{tabular}{|c|c|c|c|c|}
\hline Years of Experience & \multicolumn{2}{|c|}{ Beneficiaries } & \multicolumn{2}{c|}{ Non- Beneficiaries } \\
\hline & Frequency & Percent & Frequency & Percent \\
\hline $1-10$ & 123 & 82 & 107 & 71.3 \\
$11-20$ & 27 & 18 & 41 & 27.4 \\
21 and above & 0 & 0 & 2 & 1.3 \\
\hline Total & 150 & 100 & 150 & 100 \\
\hline
\end{tabular}

Table 8: Distribution of Cattle Fatteners According to Years of Fattening Experience

Source: Field Survey 2014

\subsection{Budgetary Analysis for Fattening Cattle}

The various components of resources utilized for fattening bull is contained in Table 9. The results show that the variable cost of $\mathrm{N} 289.02$ for fattened bull per day by the beneficiaries was obtained which constitute 33.56\% of the total costs

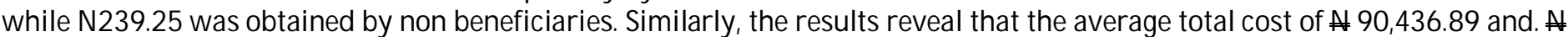
$57,572.82$ was incurred by beneficiaries and non beneficiaries respectively. This is possibly because the beneficiaries had more cattle, used high inputs and good management because they have money due to injection of credit. However, the use of high input in cattle raising ends up in high output and cattle are priced higher because of better quality of carcass. Delgado et al. (1999) noted that higher feed efficiency (lower conversion ratio) tends to encourage increased use of cereals as feed and favour those countries where cereal supply is relatively cheap and cereal feeding practices are well-established.

\begin{tabular}{|c|c|c|c|c|}
\hline & \multicolumn{2}{|c|}{ Beneficiaries } & \multicolumn{2}{|c|}{ Non Beneficiaries } \\
\hline Item & Amount $(\mathrm{N})$ & \% Of Total Cost & Amount $(\mathrm{N})$ & $\%$ Of Total Cost \\
\hline \multicolumn{5}{|l|}{ A. Revenue } \\
\hline Sales Of Fattened Cattle & 122504.29 & 135.46 & 73374.00 & 127.45 \\
\hline Sales Of Manure & 5796.00 & 6.41 & 4879.33 & 8.48 \\
\hline Total Revenue & 128300.29 & 141.87 & 78253.33 & 135.92 \\
\hline \multicolumn{5}{|l|}{ B1. Variable Cost } \\
\hline \multicolumn{5}{|l|}{ I. Feed Cost } \\
\hline Cowpea Haulms & 9270.00 & 10.25 & 7002.00 & 12.16 \\
\hline Wheat Offal/ Cereal Bran & 8806.50 & 9.74 & 6651.90 & 11.55 \\
\hline Sub Total (Variable Cost) & 18076.5 & 19.99 & 13653.9 & 23.72 \\
\hline \multicolumn{5}{|l|}{ Ii. Other Cost } \\
\hline Mineral Salt Lick & 740.00 & 0.82 & 871.00 & 1.51 \\
\hline Medication & 744.00 & 0.82 & 867.00 & 1.51 \\
\hline Water & 1932.00 & 2.14 & 1463.80 & 2.54 \\
\hline Transportation & 1586.67 & 1.75 & 1433.33 & 2.49 \\
\hline Stakes And Ropes & 510.67 & 0.56 & 540.67 & 0.94 \\
\hline Labour & 6440.00 & 7.12 & 6005.33 & 10.43 \\
\hline Commission Agents/ Tax & 317.33 & 0.35 & 286.67 & 0.50 \\
\hline Sub Total (Other Cost) & 12270.67 & 13.57 & 11467.8 & 19.92 \\
\hline Total (Variable Cost) & 30347.17 & 33.56 & 25121.7 & 43.63 \\
\hline \multicolumn{5}{|l|}{ B2. Fixed Cost } \\
\hline Fattening Stock & 36420.00 & 40.27 & 31520.00 & 54.75 \\
\hline Insurance & 1934.17 & 2.14 & 0.00 & 0.00 \\
\hline Loan Repayment & 21186.67 & 23.43 & 0.00 & 0.00 \\
\hline Depreciation On Feeding Trough & 212.22 & 0.23 & 377.78 & 0.66 \\
\hline Depreciation On Water Trough & 212.22 & 0.23 & 377.78 & 0.66 \\
\hline Depreciation On Animal Housing & 124.44 & 0.14 & 175.56 & 0.30 \\
\hline Total Fixed Cost & 60089.72 & 66.44 & 32451.12 & 56.37 \\
\hline $\begin{array}{c}\text { Total Cost (Variable + Fixed } \\
\text { Cost) }\end{array}$ & 90436.89 & 100.00 & 57572.82 & 100.00 \\
\hline Net Income & 37863.4 & 41.87 & 20680.51 & 35.92 \\
\hline
\end{tabular}

Table 9: Average Fixed and Variable Costs for Fattening One Bull for a Period of 105 Days

Source: Field Survey, 2014 


\section{Conclusion and Recommendations}

The major findings of this study suggest that majority of cattle fatteners are male, educated (whereby they either had the western education or the Q'uranic/ Arabic education or both) and are within the age bracket of 31 to 50 years hence, the productive age and they significantly affects the level of proper credit utilization by cattle fatteners. The analysis of profitability of cattle fattening in the study area revealed that micro credit has some positive impact on beneficiaries in which they realized more profit than the non beneficiaries. This is possibly because the beneficiaries had more cattle, used high inputs and good management because they have money due to injection of credit. However, the use of high input in cattle raising ends up in high output and cattle are priced higher because of better quality of carcass

This implies that if the factor is optimized and cattle fattening enterprise are promoted and supported by micro credit, they will have greater impact on the incomes and livelihood of cattle fatteners as well as improve beef production. It is concluded that micro credit scheme of the Bank Of Agriculture (BOA) Limited is a good programmed to accommodate cattle fatteners with the security to increase their income hence it is good to give credit for cattle fattening. Considering inadequate awareness on procedures of obtaining loan, it is therefore recommended that cattle fatteners can be educated on how and when to fill loan forms as well as how to use loans for the intended purposes.

\section{References}

i. Adamu, H.M., Ushie, O.A. \& Gwangwala, A.H. (2013). Estimation of total flavonoids and tannins. Int. J. Trad. Nat. Med. 2013, 3(1) Pp 19-25

ii. Armendáriz de Aghion, B. \& Morduch, J. (2010). The Economics of Microfinance, 2nd edition. Cambridge: MIT Press.

iii. Conroy, A. (2003). New Direction for Nigeria's Basic Agricultural Services: A Discussion Paper. Vol. 1 and Vol. 2: National Stakeholders Workshop on Basic Agricultural Services for Poor Farmers in Nigeria, Abuja. Pp. 1 - 63.

iv. Dawang, N.C (2011). Efficiency analysis of local chicks multiplication and production system (CMPS) in Plateau State, Nigera, MSc. Thesis. Ahmadu Bello University, Zaria, Nigeria.

v. Delgado, C., Rosegrant, M., Steinfeld, H., Ehui, S. \& Courbois, C. (1999). Livestock to 2020: The Next Food Revolution, 2020 Vision for Food, Agriculture and the Environment, Discussion Paper 28, International Food Policy Research Institute, Washington, DC.

vi. Ehigiamusoe, E.O. (2005). Microcredit: Tool for Poverty Alleviation. A Lead Paper Presented at the $12^{\text {th }}$ Annual LAPO Development Forum in Benin City On Monday, October 17th.

vii. Goldberg, N., (2005). Measuring the Impact of Microfinance: Taking Stock of What We Know. Grameen Foundation USA Publication Series 1. http:/ / www.givewell.org/ files/ causel-2/ independentresearchonmicrofinance/ Retrieved 2012-10-06

viii. Maiyama, A.A. (1985). Problems of Agricultural Production as perceived by certain small scale farmers of Sokoto State, Nigeria. A Thesis submitted to the Faculty of Graduate Studies, Virginia State University, U.S.A Pp. 1-56

ix. Mohammed, A.D. \& Hassan, Z. (2008). "Microfinance in Nigeria and the Prospects of introducing its Islamic version there in the Light of selected Muslim countries' Experience" MPRA paper no. 827 - http:/ / mpra.ub.uni.muenchem.de/ 8287/

x. Musaba, E.C., (2010). Analysis of factors influencing adoption of cattle management technologies by communal farmers in Northern Namibia, Livestock Research for Rural Development 22. .http://www.lrrd.org/lrrd22/6/musa22104.htm. Accessed 12 January 2014

xi. National Population Commission. (2007). "Nigeria's National Census" Population Census of Ilesa, Osun State, Nigeria". Federal Republic of Nigeria Gazette, National and State Provisional Total Census, Printed and Published by Federal Government Printer, Lagos, Nigeria. 21(94): 175-200.

xii. Okebioru, E.O. \& Jatto, N.A (2017). Value Addition in Caasava Processing: Evidence from Women in Ilesa West Local Government Area of Osun State. Journal of Agriculture and Food Sciences Research, 4(1): 30-36.

xiii. Okoh, R.N, Ugwunba, C.OA \& Isitor, S.U (2009). Micro finance for small scale enterprises development in Anambra State, Nigeria: AGender Analysis. Nigeria Journal for Research and production: 15(2): Pp.145 - 159

xiv. Okoruwa, V.O., Obadia, F. O. \& Ibrahim, G. (2005). Profitability of beef cattle fattening in the Cosmopolitan city of Ibadan, Oyo State. Moor J. Agric. Res, 6(1) Pp.45-51.

xv. Okoye, C. (2007). "Situational Status of Microfinance Institutions" A paper presented at the African Institute for Applied Economics, Enugu Forum Policy Paper 7.

xvi. Oladeebo, J.O \& Oladeebo, O.E (2008). Determinant of Loan Repayment among Smallholder Farmers in Ogbomoso Agricultural Zone of Oyo State, Nigeria. Journal of Social Science, 17(1) Pp 59-62.

xvii. Oloruntoba, A (2000). "Evaluation of Manpower Training Programmed on Job Behaviour of Senior Agricultural Research Management in Nigeria". Unpublished PhD Thesis, Departmentb of Agricultural Extension and Rural Development, University of Ibadan.

xviii. Olukosi, J.O. \& Erhabor, P.O. (1989). Introduction to Agricultural Production Economics, Agitab Publishers, Zaria, Kaduna, Nigeria Pp.112

xix. Sokoto State Government Dairy (SOSG, 2007). Yearly Publication by the Home Affairs Depatment, Sokoto State. Pp.1-3.

xx. Sokoto State Guide to Economic potential, (2008). Yearly Publication by the Ministry of commerce, Industry and Tourism, Sokoto State. Pp.1-31.

xxi. Tazul, I. (2007). Microcredit and Poverty alleviation. Ashgate Publishing, Ltd. 